\title{
Synthesis of 3-phenyl-1H-pyrazole Derivatives
}

\author{
Xiaobo Liu, Shan Xu and Yinhua Xiong ${ }^{a^{*}}$ \\ School of Pharmacy, Jiangxi Science \& Technology Normal University, Nanchang 330013, China \\ ${ }^{* a}$ xiongyhfriend@126.com \\ *The corresponding author
}

Keywords: 3-Phenyl-1H-pyrazole; Synthesis; Acetophenone

\begin{abstract}
H-pyrazole (1) is an important intermediate for the synthesis of many biologically active compounds. It was synthesized from acetophenone (2) and hydrazine through two steps including Knoevenagel condensation, Cyclization reaction reaction. In this paper, three novel 3-phenyl-1H-pyrazole derivatives were prepared. The structure were confirmed by MS and ${ }^{1}$ H NMR. Furthermore, the synthetic method was optimized. The total yield of the two steps were $80 \%$.
\end{abstract}

\section{Introduction}

In today's society, cancer is a serious threat to human health and life, although the traditional method of treatment of cancer is simple and quick, but there is a big drawback ${ }^{[1]}$. Tumor molecular targeted therapy using tumor cells and normal cells between the molecular biology of the differences, blocking the signal transduction pathway, blocked receptors, inhibition of angiogenesis and other methods specific role in tumor cell targets, specific Inhibit tumor cell proliferation, invasion and metastasis, and promote its apoptosis ${ }^{[2-3]}$. Because of the specificity of the target, molecular targeted therapy is more selective than traditional chemotherapy and has less side effects. Therefore, molecular targeted therapy for cancer has been widely concerned in cancer therapy because of its safe and high efficiency ${ }^{[4-5]}$. In recent years, there are many small molecular targeted anticancer drugs have been reported. Among them, 3-phenyl-1H-pyrazole (1) is an significant intermediate for the synthesis of many biologically active compounds. Therefore, design and synthesis of compound 1 derivative as small molecule inhibitors played a essential role in the study of anticancer.

Many compound 1 derivatives which exhibited potential biological activities, such as methyl 2-((1-(4-chlorophenyl)-1H-pyrazol-3-yloxy)methyl)phenyl(methoxy)carbamate $\mathrm{N}-\left(\left(1 \mathrm{H}-\right.\right.$ pyrazol-1-yl)methyl)-N-(3-chloroprop-1-en-2-yl)-2,6-dimethylbenzenamine $(4)^{[7]}$, methyl 3-(4-chlorophenyl)-4-methyl-1-((4-(trifluoromethyl)phenyl)carbamoyl)-4,5-dihydro-1H-pyrazole-4carboxylate (5) ${ }^{[8]}$, ethyl 3-methyl-5-oxo-1-phenyl-4,5-dihydro-1H-pyrazole-4-carboxylate (6) ${ }^{[9]}$, 5-(4-chlorophenyl)-1-(2,4-dichlorophenyl)-4-methyl-1H-pyrazole-3-carboxylic acid (7) ${ }^{[10]}$, these compound 1 derivatives showed biological activity.

Most of the synthetic methods of compound 1 which reported in the literature have the drawbacks such as longer synthetic route, lower yield and harmful to environment. Therefore, the optimization of the synthetic route and methods of compound 1 is necessary. In this study, we prepared three kinds of compound 1 derivatives, and design and optimize the method of the sythesis of compound 1, making it more suitable for industrial production. The structures of representative compounds were shown in Fig. 1. 
<smiles>COC(=O)N(OC)c1ccccc1COc1ccn(-c2ccc(Cl)cc2)n1</smiles>

3<smiles>C=C(Nc1ccc(C(F)(F)F)cc1)N1CC(C)(C(=O)OC)C(c2ccc(Cl)cc2)=N1</smiles><smiles>Cc1c(C(=O)O)nn(-c2ccc(Cl)cc2Cl)c1-c1ccc(Cl)cc1</smiles>

7<smiles>C=C(CCl)N(Cn1cccn1)c1c(C)cccc1C</smiles>

4<smiles>CCOC(=O)C1C(=O)N(c2ccccc2)N=C1C</smiles>

6

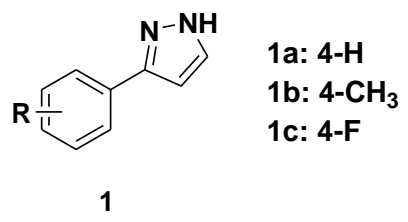

Figure 1. Structure of representative 3-phenyl-1H-pyrazole derivatives

\section{Materials and Methods}

NMR spectra were performed using Bruker $400 \mathrm{MHz}$ spectrometers (Bruker Bioscience, Billerica, MA, USA) with TMS as an internal standard. Mass spectra (MS) were taken in ESI mode on Agilent 1100 LC-MS (Agilent, Palo Alto, CA, USA). All the materials were obtained from commercial suppliers and used without purification, unless otherwise specified. Yields were not optimized. TLC analysis was carried out on silica gel plates GF254 (Qindao Haiyang Chemical, China).

\section{Synthesis of compounds}

The structures and the synthetic route were shown in Scheme 1.

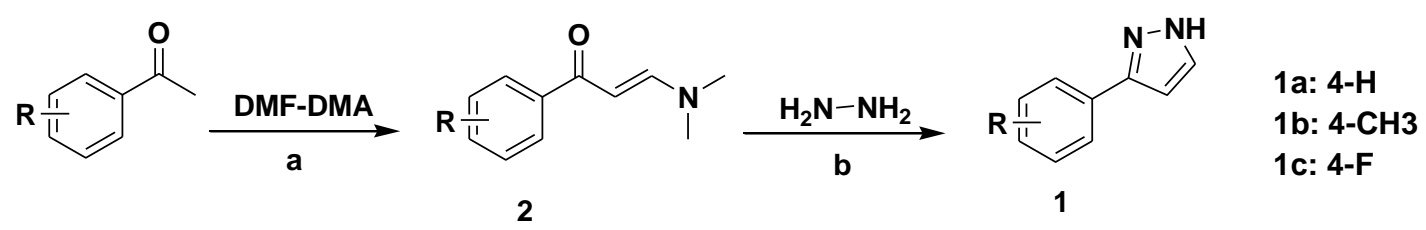

Scheme 1. The synthetic route of compound 1a-1c

Reagents and Conditions: (a) DMF-DMA, $100^{\circ} \mathrm{C}, 5 \mathrm{~h}$; (b) hydrazine, $\mathrm{C}_{2} \mathrm{H}_{5} \mathrm{OH}, 80^{\circ} \mathrm{C}, 2 \mathrm{~h}$.

(E)-3-(dimethylamino)-1-phenylprop-2-en-1-one (2a). acetophenone (5.0 g, $416 \mathrm{mmol}$ ) was dissolved in DMF-DMA $(50 \mathrm{~mL})$, then the mixture was heated to $100^{\circ} \mathrm{C}$ and refluxed for $5 \mathrm{~h}$. After the completion of the reaction (monitored by TLC). The mixture was cooled to room temperature, and poured into petroleum ether with stirred for $30 \mathrm{~min}$. filtered and the precipitate was washed with ethanol then the residue was dried to obtain a powdery solid $(6.7 \mathrm{~g}, 92.1 \%)$. MS : 176.1 $[\mathrm{M}+\mathrm{H}]^{+}$.

3-phenyl-1H-pyrazole (1a). (E)-3-(dimethylamino)-1-phenylprop-2-en-1-one (2) (0.5 g, 286 
mmol) and hydrazine $(3 \mathrm{~mL})$ dissolve in ethanol $(20 \mathrm{~mL})$, then the mixture was heated to $80^{\circ} \mathrm{C}$ and refluxed for $2 \mathrm{~h}$. After the completion of the reaction (monitored by TLC). The mixture was cooled to room temperature, and poured into water with stirred for $30 \mathrm{~min}$. The mixture was filtered then the residue was dried to obtain a powdery solid $(0.383 \mathrm{~g}, 93.2 \%)$. MS: $145.0[\mathrm{M}+\mathrm{H}]^{+}$. ${ }^{1} \mathrm{H}$ NMR $(400 \mathrm{MHz}, \mathrm{DMSO}) \delta 12.88(\mathrm{~s}, 1 \mathrm{H}), 7.69(\mathrm{t}, \mathrm{J}=19.2 \mathrm{~Hz}, 3 \mathrm{H}), 7.32(\mathrm{t}, \mathrm{J}=7.2 \mathrm{~Hz}, 2 \mathrm{H}), 7.21(\mathrm{~d}, \mathrm{~J}=$ $6.9 \mathrm{~Hz}, 1 \mathrm{H}), 6.62(\mathrm{~s}, 1 \mathrm{H})$.

3-p-tolyl-1H-pyrazole (1b). Experimental operation as (1a). (0.414 g, 91.3\%). ESI -MS m/z: $159.0[\mathrm{M}+\mathrm{H}]^{+} .{ }^{\mathrm{l}} \mathrm{H}$ NMR (400 MHz, DMSO) $\delta 12.96(\mathrm{~s}, 1 \mathrm{H}), 7.61(\mathrm{~d}, \mathrm{~J}=8.8 \mathrm{~Hz}, 3 \mathrm{H}), 7.13(\mathrm{~d}, \mathrm{~J}=$ $7.4 \mathrm{~Hz}, 2 \mathrm{H}), 6.57(\mathrm{~s}, 1 \mathrm{H}), 2.22(\mathrm{~s}, 3 \mathrm{H})$.

3-(4-fluorophenyl)-1H-pyrazole (1c). Experimental operation as (1a). (0.428 g, 92.5\%). ESI -MS m/z: $162.1[\mathrm{M}+\mathrm{H}]^{+} .{ }^{1} \mathrm{H}$ NMR (400 MHz, DMSO) $\delta 13.12(\mathrm{~s}, 1 \mathrm{H}), 7.74(\mathrm{dd}, \mathrm{J}=16.5,9.4 \mathrm{~Hz}$, 2H), $7.64(\mathrm{~s}, 1 \mathrm{H}), 7.15(\mathrm{t}, \mathrm{J}=8.7 \mathrm{~Hz}, 2 \mathrm{H}), 6.62(\mathrm{~d}, \mathrm{~J}=1.1 \mathrm{~Hz}, 1 \mathrm{H})$.

\section{Conclusions}

In conclusion, 3 kinds of 3-phenyl-1H-pyrazole (1) derivatives were prepared by substituted acetophenone and hydrazine through two steps including Knoevenagel condensation, Cyclization reaction reaction. The synthetic compound 1 derivatives and the reactions conditions were optimized, the yield of the product was much more higher, and making it more suitable for industrial production. It structure was confirmed by MS and 1H NMR spectrum.

\section{Acknowledgments}

We gratefully acknowledge the generous support provided by Project supported by the Natural Science Foundation of Jiangxi Province (81660692), Doctoral Scientific Research Foundation of Jiangxi Science \& Technology Normal University and Science and Technology Project Founded by the Education Department of Jiangxi Province (No. GJJ14598).

\section{References}

[1] Hegyi G, Szasz O, Szasz A. Oncothermia: a new paradigm and promising method in cancer therapies. Acupuncture \& electro-therapeutics research, 2013, 38(3-4):161-197.

[2] Bussolati B, Deambrosis I, Russo S, et al. Altered angiogenesis and survival in human tumor-derived endothelial cells. The American Societies for Experimental Biology, 2003, 17(9): $1159-1161$.

[3] Semenza G L. Targeting HIF-1 for cancer therapy. Nature reviews cancer, 2003, 3(10): 721-732.

[4] Hurley L H. DNA and its associated processes as targets for cancer therapy. Nature Reviews Cancer, 2002, 2(3): 188-200.

[4] Ji S, Liu C, Zhang B, et al. Carbon nanotubes in cancer diagnosis and therapy. Biochimica et Biophysica Acta (BBA)-Reviews on Cancer, 2010, 1806(1): 29-35.

[5] Bringolf R B, Cope W G, Eads C B, et al. Acute and chronic toxicity of technical - grade pesticides to glochidia and juveniles of freshwater mussels (unionidae). Environmental Toxicology and Chemistry, 2007, 26(10): 2086-2093.

[6] Mohr S, Feibicke M, Berghahn R, et al. Response of plankton communities in freshwater pond and stream mesocosms to the herbicide metazachlor. Environmental Pollution, 2008, 152(3): 530-542.

[7] Khambay B P S, Denholm I, Carlson G R, et al. Negative cross-resistance between dihydropyrazole insecticides and pyrethroids in houseflies, Musca domestica. Pest management science, 2001, 57(9): 761-763. 
[8] Chande M S, Bhat U S. Design and Synthesis of New Spiroheterocycles: Selective Role of Potassium Fluoride in DMF. ChemInform, 2006, 37(34): 1041-1047.

[9] Dyck B, Goodfellow V S, Phillips T, et al. Potent imidazole and triazole CB 1 receptor antagonists related to SR141716. Bioorganic \& medicinal chemistry letters, 2004, 14(5): 1151-1154. 